\title{
Çalışma Sermayesi Yönetiminin Kârlılığa Etkisi: Borsa İstanbul 50 Endeksi Örneği*
}

İlknur ESKİ**

\author{
Batuhan GÜVEMLi்**
}

\section{$\ddot{O Z Z E T}$}

$B u$ çalı̧̧ma işletme sermayesi bileşenlerinin kârlılık üzerindeki etkilerini incelemektedir. Bu amaçla Borsa İstanbul (BIST) 50 endeksinde işlem gören ve mali kuruluş olmayan 33 işletmenin 20122016 yllları arasındaki finansal ve finansal olmayan verileri çoklu regresyon ve korelasyon yöntemleri ile analiz edilmiştir. Çalışma sonuçlarına göre ilgili şirketlerin nakit dönüşs süreleri ile hem aktif kârlılığ hem de faaliyet kârı arasında anlamlı iliş̧ki belirlenememiştir. Buna karşın aktif kârlılı̆̆l ile şirket yaşı arasında, likidite oranı ile nakit dönüş süresi arasında, faaliyet kârı ile finansal kaldıraç arasinda, çalışan saylst ile şirket büyüklügü arasında pozitif yönlü bir iliş̧ki tespit edilmiştir.

Anahtar Kelimeler: Çalışmasermayesi, nakit dönüşs süresi, işletme kârlılığı.

JEL Sinıflandırması: M41, M49.

\section{Effect of Working Capital Management on Profitability: Evidence from Borsa Istanbul 50 Index}

\section{ABSTRACT}

We investigate the relation between working capital components and corporate profitability for a sample of 33 non-financial firms quoted at the Borsa Istanbul (BIST) 50 Index for the 2012-2016 period. Cash conversion cycle is used as a comprehensive measure of Working capital management. Multiple correlation and regression analyses results indicate that there is no significant relationship between cash conversion cycle, operational income and return on assets. Findings also indicate a strong relationship between return on assets and firm age, liquidity ratio and cash conversion cycle, number of employees and firm size.

Keywords: Working capital management, cash conversion cycle, corporate profitability.

Jel Classification: M41, M49.

\footnotetext{
* Makale Gönderim Tarihi: 29.04.2019, Makale Kabul Tarihi: 13.07.2019, Makale Türü: Araştırma Makalesi
}

* Dr. Öğr. Üyesi. Trakya Üniversitesi, Uzunköprü Uygulamalı Bilimler Yüksekokulu, lknureskin@hotmail.com, Orcid ID: 0000-0003-2306-7315

** Prof. Dr., Trakya Üniversitesi, İktisadi ve İdari Bilimler Fakültesi, bguvemli@yahoo.com,

Orcid ID: 0000-0002-2985-5198 


\section{GİRIŞ}

Dönen varlıklar ile cari yükümlülüklerin yönetimi olarak ifade edilen çalışma sermayesi yönetimi başarılı şirket yönetiminde anahtar rol üstlenmektedir (Karadeniz, 2012: 123). 1955 yılında, Ford Motor şirketinin üst düzey yöneticilerinden John Sagan, etkin nakit yönetimi ile ticari alacakların nakde dönüş süresinin on günden iki güne indirilebileceğini ve sekiz gün boyunca elde tutulan nakdin yatırımlarda kullanılabilecek bir enstrümana dönüşebileceğini açıklamaktadır (Sagan, 1955).Zeidan ve Shapir 'in (2017) Brezilya'da emlak şirketi MRV'nin 2010-2015 dönemine ilişkin nakit dönüş sürelerini inceledikleri çalışmada, şirketin 2012 yılında 508 gün olan nakit dönüş süresini 2015 yılında 351 güne indirdiğindesermaye ihtiyacını 1.02 milyar dolar azalttığını belirtmektedirler.Bu örneklerdeki gibi, işletmeler nakde daha çabuk ulaştıkça faydalanabilecekleri bir sermaye ortaya çıkmaktadır. Ortaya çıkan tutar, dış finansman ihtiyacını azaltacak ve daha yüksek getiriler için tekrar yatırıma dönüştürülebilecektir. $\mathrm{Bu}$ nedenle çalışma sermayesi politikaları şirketlerin likiditesi, riski, kârlılığı ve dolayısıyla şirket değeri üzerinde önemli etkiye sahiptir (Dinçergök, 2019: 162)(Saldanlı, 2012: 168). Ayrıca, işletmelerin hem iç ve dış pazarlarda yaşadığı yoğun rekabet koşulları hem de yaşanan ekonomik kriz dönemi nakit yönetimi ve likidite kontrolünün önemini daha çok arttırmıştır (Karadeniz, 2012: 123).

Nakit dönüş süresi,işletme sermayesi yönetiminin etkinliğini ölçen önemli bir bileşendir ve hammadde alım harcamaları ile mamul satışlarının tahsilatı arasında geçen süreye odaklanır(Yücel ve Kurt, 2002: 2) (Topaloğlu ve Nur, 2016: 305).

Nakit dönüş süresinin uzun veya kısa olması muhtemeldir. İşletmenin stoklarını hızlı bir şekilde nakde dönüştürmesi, alacaklarını tahsil etmesi ve daha düşük maliyetli olan ticari borçlarını arttırması, günlük işlemlere daha az fon bağlamasını ve daha pahalı olan dış finansman bağlılığını azaltacak ve bu durum kârlılığı artıracaktır (Coşkun ve Kök, 2011:77). Diğer taraftan nakit dönüş süresinin uzaması da satışların artması nedeni ile kârlılığı artırabilir(YazdanfarveÖhman, 2014: 443).Bunun yanında eğer çalışma sermayesine yapılan yatırımın maliyeti stoklara ve ticari alacaklara olan yatırımdan sağlanan faydadan daha fazla ise bu durumda nakit dönüş süresinin uzaması kârlılığı azaltıcı bir etken oluşturur (Keskin ve Gökalp, 2016:16).

Nakit dönüş süresinin uzun olması, diğer ifadeyle pozitif olması, söz konusu işletmenin borçlanma ihtiyacında olduğunun göstergesidir ve işletmenin çalışma sermayesine o oranda fazla yatırım yapması gerektiğini gösterebilir (İşeri ve Chambers,2003:2).Nakit dönüş süresinin kısa veya negatif değerde olması ise, söz konusu işletmenin çalışma sermayesi finansmanı için ticari borçlarındanfaydalanabildiğini göstermektedir. Genel olarak perakendecilik sektöründe faaliyet gösteren işletmelerin negatif nakit dönüş süresine sahip olduğu belirtilmektedir. Bunun sebebi stokların ortalama tüketim süresinin düşüklüğü ve nakit ağırlıklı satış süreçleridir (Ege vd., 2016 :181). Ayrıca, söz konusu işletmeler bankalardan ticari kredi taleplerinde bulunarak genellikle alacaklarının \%70-80'i civarında borçlanıp kalan finansmanı da özkaynak ile temin etme yoluna giderler (Sakarya, 2008: 237).

Nakit dönüş süresi, para ve sermaye piyasalarına daha iyi erişimi olan büyük işletmelere göre daha az finansal kaynaklara sahip küçük işletmelerin likiditelerini değerlendirmede daha faydalı bir yoldur. Küçük işletmeler nakit dönüş sürelerini kısaltarak önemli bir finansman kaynağı sağlayabilirler (Nobanee vd., 2011:153). Ebben ve Johnson 
(2011) 1752 adet küçük ölçekli işletmenin nakit yönetimini inceledikleri çalışmada, daha verimli nakit dönüş süresi olan işletmelerin daha az finansman ihtiyacı duyduklarını ve bununişletmelerinfinansal performansları üzerinde olumlu etki yaptığını açıklamaktadırlar. Tran vd., (2017) Vietnam'da faaliyet gösteren 200 adet küçük ve orta ölçekli işletmenin nakit yönetiminiinceledikleri çalışmada aynı sonuçları açıklamaktadırlar.

Çalışmanındiğer bölümlerinde sırasıyla literatür özetlenmiş, çalışmanın örneklemi, değişkenleri açıklanmış, korelasyon ve regresyon modellerinden elde edilen bulgulara yer verilmiştir.Sonuç bölümünde ise araştırmanın genel değerlendirilmesi yapılmıştır.

\section{LITERATÜR ANALİZi}

Çalışma sermayesinin şirket kârlılığı üzerinde etkisini ölçen uluslararası ve ulusal birçok çalışma bulunmaktadır. Bu çalışmaların farklı ülkelerde çeşitli sektörlerde yapıldığ 1 görülmektedir. Birçok çalışmada nakit dönüş süresi ile kârlılık arasında negatif ilişki tespit edilmiştir. Manuelvd.,(1996) çalışma sermayesinin şirketin aktif kârlılığına ve öz sermaye kârlılığına etkisini ölçmek amacıyla 20 yıllık dönemde 2.718 şirketi regresyon analiz yöntemi ile incelemişlerdir. Analiz sonuçlarına göre nakit dönüş süresi ile kârlılık arasında negatif ilişki tespit edilmiştir.Deloof (2003) Belçika'da 1992-1996 dönemine ilişkin 1.009 adet büyük ölçekli şirketin stok devir hızı, alacak devir süresi ve borç ödeme süresi ile aktif kârı arasındaki ilişkiyi regresyon analiz yöntemi ile incelemiş ve sonuç olarak negatif ilişki tespit etmiştir.Uyar (2009) 2007 yılında İstanbul Menkul Kıymetler Borsası'nda (İMKB)hisseleri işlem gören pazarlama ve imalat işletmelerinin nakit dönüş sürelerinin aktif kârlılı̆ğ, özsermaye kârlılığı ve büyüklük arasında ilişkiyi analiz etmiş ve bu değişkenler arasında negatif ilişki tespit etmiştir. Nobanee vd., (2011) Japonya'da 1990-2004 yıllarında Tokyo Borsası'nda işlem gören 34.771 adet şirketin nakit dönüş süresi ile yatırımların getirisi arasında ilişkiyi analiz etmişlerdir.Çalışmada perakende ve hizmet sektörü dişında kalan şirketlerin nakit dönüş sürelerinin uzunluğu ile kârlılıkları arasında negatif ilişski tespit edilmiştir.Mansoori ve Muhammed (2012) Singapur Borsasında hisseleri işlem gören 92 adet şirketin nakit dönüş süresi ile aktif kârlılığı arasındaki ilişkiyi analiz etmişler ve bu değişkenler arasında negatif ilişki tespit etmişlerdir. Yazdanfar ve Öhman (2014) İsveç’te 2008-2011 dönemine ilişkin 13.797 adet Küçük ve Orta Büyüklükteki İşletmeler 'in (KOBİ) nakit dönüş süreleri ile aktif kârlılıkları arasındaki ilişkiyi analiz etmişlerdir. Çalışma sonuçlarına göre; KOBİ'lerin nakit dönüşs süresi ile kârlılığ 1 arasında negatif ilişki olduğu, işletme büyüklügünün işletme kârına olumlu etkilediği, işletme yaşının işletme kârını olumsuz yönde etkilediği, daha genç KOBİ'lerin kârlılıkla ilişkisinin daha uzun yıllar faaliyette bulunanlara göre olası olduğu belirlenmiştir.Murugesu (2014) Sri Lanka' daki 20082012 döneminde tarım sektöründe yer alan işletmelerin nakit dönüş süresi ile aktif kârlılığı, öz sermaye kârlılı̆̆ı ve net kârı arasındaki ilişkiyi analiz etmiş ve sonuç olarak negatif ilişki tespit etmiştir.

Bazı çalışmalarda ise nakit dönüş süresi ile kârlılık arasında pozitif ilişki bulunmuştur. Gill vd., (2010) New York Borsasında hisseleri işlem gören 2005-2007 dönemine ilişkin 88 adet Amerikan üretim işletmesinin çalışma sermayesi ile brüt faaliyet kârlılık arasındaki ilişkiyi incelemişler ve değişkenler arasında pozitif ilişki tespit etmişlerdir. Sharma ve Kumar (2011) Hindistan Borsası 500 endeksinde yer alan 263 adet işletmenin çalışma sermayesi yönetiminin aktif kârlılığına etkisini araştırmışlardır. Çalışmada, nakit dönüşsüresi ile aktif kârlılığg arasında pozitif ilişki belirlenmiştir. Türkiye'de bu konu ile ilgili yapılan 
çalışmalarda benzer sonuçlara ulaşılmıştır. Sakarya (2008) İMKB' de hisseleri işlem gören 43 KOBİ niteliğindeki işletmenin 2003-2006 yılları arasındaki verilerini incelemiş ve bu şirketlerin nakit yönetim etkinliğini araştırmıştır. Çalışma sonuçlarına göre; incelenen işletmelerin büyük çoğunluğunun nakit dönüş süresinin pozitif olduğu, buna karşıllk bazı işletmelerin (toplam43 işletmeden 10 işletmenin 15 dönemde) negatif bir nakit dönüş süresine sahip oldukları, imalat sektöründe yer alan alt sektörlerde nakit dönüş süresinin farklılık gösterdiği belirlenmiştir.

Nakit dönüş süresinin sektörel bazda etkinliğini ölçen çalışmalar da mevcuttur. Karadeniz (2012) İMKB' de hisseleri işlem gören turizm işletmelerinin nakit dönüşsürelerini 2002-2010 yılları arasında incelemiş ve Türkiye Cumhuriyeti Merkez Bankası (TCM) tarafından hazırlanan otel ve lokantalar sektör ortalamalarıyla karşılaştırmıştır. Çalışmada otel ve lokantalar sektörünün nakit dönüş süresi ortalamada negatif olduğu tespit edilmiştir. Çalışma, turizm sektöründe nakit dönüş süresinin uzunluğuna stok devir süresinin, alacak devir süresinden daha fazla etki ettiğini belirlemiştir. Konuk ve Zeren (2014) Türkiye'deki BİST endeksinde yer alan yiyecek içecek sektöründeki işletmelerin optimum nakit dönüş sürelerine sahip olup olmadıklarını incelemişlerdir. Çalışmada 2008-2013 dönemine ilişkin 15 işletmenin verilerinden yararlanılmıştır. Çalışma sonuçlarına göre yiyecek içecek sektöründeki işletmelerin optimal çalışma sermayesine sahip olmadığ 1 , nakit dönüş süresinin uzun vadede ortalamadan farklı ve değişken olduğu belirlenmiştir. Bunun sebebi olarak da Türkiye ekonomisinin krizlere karşı savunmasız olduğu gösterilmiştir. Dinçergök (2019), BİST endeksinde yer alan kimya, petrol, kauçuk ve plastik sektöründeki işletmelerin çalışma sermayesi yönetimi ile kârlılık ilişkisini incelemiştir. Çalışmada 2005- 2016 dönemine ilişkin 25 işletmenin verilerinden faydalanılmıştır. Araştırmada kârlılık göstergesi olarak faaliyet kârı ve faiz ve vergi öncesi kâr kullanılmıştır. Çalışma sonuçlarına göre alacak tahsil süresi ve kârlılık oranları arasında doğrusal olmayan bir ilişki tespit edilmiştir. Konak ve Güner (2016), 2011-2014 döneminde BIST imalat sektöründe yer alan işletmelerde çalışma sermayesi yönetimi ile şirket karlılığı arasındaki ilişkiyi incelemiş ve net kâr marjı ile nakit dönüş süresi ve kısa vadeli borç ödeme hızı arasında belirgin negatif ilişki tespit etmişlerdir.

\section{ARAŞTIRMA YÖNTEMİ VE VERILER}

Çalışmanın bu bölümünde, araştırmanın amacı ve kapsamı, metodolojisi ve bulguların değerlendirilmesiyle ilgili bilgilere yer verilmiştir.

\subsection{Araştırmanın Amacı ve Kapsamı}

Çalışmanın temel amacı çalışma sermayesinin şirketlerin performanslarına etkisini ölçmektir. Bu amaç doğrultusunda BİST 50'de işlem gören ve mali kuruluş olmayan 33 şirketin 2012-2016 yılları arasındaki aktif kârlılıkları, faaliyet kârları, likiditeleri, finansal kaldıraçları ve nakit dönüş süreleri hesaplanmıştır. Çalışmaya BİST 50'deki bankacılık ve sigortacılık sektöründe yer alan şirketler dâhil edilmemiştir. Şirketin büyüklük ölçüsü olarak net satışlar dikkate alınmıştır. Finansal olmayan veri olarak şirketin yaş ve çalışan sayıları verilerinden faydalanılmıştır. Çalışmaya dâhil edilen şirketler Borsa İstanbul'da yer alan sınıflandırmaya bağlı olarak gruplandırılmıştır. Buna göre; taş ve toprağa dayalı, metal ana sanayi, gıda, içki ve tütün, perakende, elektrik, gaz ve su, kimya, petrol, kauçuk ve plastik ürünler, metal eşya, makine ve gereç yapım, teknoloji, ulaştırma, haberleşme ve depolama, inşaat ve bayındırlık ve holdingler olmak üzere 11 sektörde gruplandırma yapılmıştır. Söz 
konusu yıllara ait veriler Kamu Aydınlatma Platformunun web sayfasından ve şirketlerin kurumsal web sayfalarından elde edilmiştir.

\subsection{Araştırmanın Metodolojisi}

Çalışmada öncelikle 33 şirketin 2012-2016 yılları arasındaki yıllık finansal ve finansal olmayan verilerinden yararlanarak aktif kârlılı̆̆ı, faaliyet kârı, likiditesi, finansal kaldıracı, nakit dönüş süresi, net satışları, yaşı ve çalışan sayısının beş yıllık ortalamaları hesaplanmıştır. Daha sonra bu verilerin sektörelbazda ortalamalarıhesaplanmıştır. Yapılan bu hesaplamalardan elde edilen sonuçlar Tablo 2'de yer almaktadır. Sektörler itibariyle elde edilen veriler SPSS V20 programına aktarılarak, değişkenler arasında korelasyon analizi ve ileri sürülen hipotezlerin regresyon analizi ile testi yapılmıştır. Çalışmada kullanılan 8 adet değişken, bu değişkenlerin nasıl hesaplandığı ve literatürde bu değişkenlerin kullanıldığ 1 çalışmalar Tablo 1'de belirtilmiştir.

Tablo 1. Analizde Kullanılan Değişkenler ve Formüller

\begin{tabular}{|c|c|c|}
\hline Değişkenler & Formül & Literatür \\
\hline \multicolumn{3}{|l|}{ Bağımlı Değişkenler } \\
\hline Aktif Kârlılık & Net Kâr / Toplam Aktif & Baños-Caballero(2014) \\
\hline Faaliyet Kârlılığı & Faaliyet Kârı / Toplam Aktif & Padachi (2006) \\
\hline \multicolumn{3}{|l|}{ Bă̆ımsız Değişken } \\
\hline Nakit Dönüş Süresi & $\begin{array}{l}\text { Stok Devir Süresi }+ \text { Ticari Alacak } \\
\text { Devir Süresi - Ticari Borç Ödeme } \\
\text { Süresi }\end{array}$ & Shin ve Seonen (1998) \\
\hline \multicolumn{3}{|l|}{ Kontrol Değişkenleri } \\
\hline Finansal Kaldıraç & Toplam Borçlar/ Toplam Varlıklar & Aregbeyen (2013) \\
\hline Likidite Oran & $\begin{array}{l}\text { Dönen Varlıklar- K.V.B. / Toplam } \\
\text { Aktifler }\end{array}$ & Shin ve Seonen (1998) \\
\hline Şirket Yaşı & $\begin{array}{l}\text { Şirketin kurulduğu tarihten } 2016 \\
\text { yılına kadar geçen süre }\end{array}$ & Sharma ve Kumar (2011) \\
\hline Şirket Büyüklüğü & Net Satışlar & Deloof (2003) \\
\hline Çalışan sayısı & Şirkette çalışanların sayıları & Yazdanfar ve Öhman (2014) \\
\hline
\end{tabular}

Tablo 1'de belirtilen literatüre uygun olarak aşağıdaki hipotezler geliştirilmiştir.

H1: Nakit dönüşs süresi ile aktif kârlılık arasında ilişki vardır.

H2: Nakit dönüş süresi ile faaliyet kârı arasında ilişki vardır.

H3: Şirketin büyüklüğü ile faaliyet kârı arasında ilişki vardır.

H4: Şirket büyüklüğü ile aktif kârlılık arasında ilişki vardır.

H5: Şirket yaşı ile aktif kârlılık arasında ilişki vardır.

H6: Şirket yaşı ile faaliyet kârı arasında ilişki vardır

H7: Çalışan sayısı ile aktif kârlılık arasında ilişki vardır. 
H8: Çalışan sayısı ile faaliyet kârı arasında ilişki vardır.

Tablo 2'de değişkenlerin sektörel ortalaması yer almaktadır. Tabloda,perakende, ulaştırma, haberleşme ve depolama sektöründe yer alan şirketlerin ortalama nakit dönüş sürelerinin eksi, elektrik, gaz ve su tüketim sektöründe yer alan şirketlerin nakit dönüş sürelerinin kısa olduğu görülmektedir. Bu sürenin eksi veya kısa olması bu sektörlerdeki şirketlerin stoklarını tüketim sürelerinin düşük ve nakit ağırlıklı satış yapmalarından kaynaklanmaktadır. Diğer taraftan teknoloji, metal ve taş, toprak sektöründe yer alan şirketlerin stoklarını tüketim süreleri ve alacaklarını tahsil etme sürelerinin uzun olmasına bağlı olarak nakit dönüş süreleri uzundur.

Tablo 2. Değişkenlerin Sektörel Ortalaması ( 2012-2016 Yıllarının Ortalaması)

\begin{tabular}{|c|c|c|c|c|c|c|c|c|}
\hline Sektörler & $\begin{array}{l}\text { Aktif } \\
\text { Kârlılık }\end{array}$ & $\begin{array}{l}\text { Faaliyet } \\
\text { Kârlılığı }\end{array}$ & $\begin{array}{l}\text { Nakit } \\
\text { Dönüş } \\
\text { Süresi }\end{array}$ & $\begin{array}{l}\text { Finansal } \\
\text { Kaldıraç } \\
\text { Oranı }\end{array}$ & $\begin{array}{l}\text { Likidite } \\
\text { Oran }\end{array}$ & $\begin{array}{l}\text { Şirket } \\
\text { Yaşı }\end{array}$ & $\begin{array}{l}\text { Şirket } \\
\text { Büyüklüğüu }\end{array}$ & $\begin{array}{l}\text { Çalışan } \\
\text { Sayıları }\end{array}$ \\
\hline Taş, Toprak & 0,0638 & 0,0933 & 102,52 & 0,31 & 0,3072 & 60 & 3.023 .891 & 8.306 \\
\hline Metal & 0,0520 & 0,1550 & 125,10 & 0,45 & 0,1689 & 40 & 6.464 .212 & 8.173 \\
\hline Gıda, İçki, Tütün & 0,0368 & 0,1251 & 37,99 & 0,48 & 0,1302 & 27 & 7.539 .544 & 13.121 \\
\hline Perakende & 0,0544 & 0,4451 & $-34,89$ & 0,74 & $-0,0717$ & 42 & 11.589 .952 & 24.277 \\
\hline Elektrik, Gaz, Su & $-0,004$ & 0,1352 & 15,39 & 0,74 & 0,0443 & 23 & 1.699 .034 & 475 \\
\hline $\begin{array}{l}\text { Kimya, Petrol, } \\
\text { Kauçuk, } \\
\text { Plastik }\end{array}$ & 0,0647 & 0,1667 & 40,09 & 0,50 & 0,0825 & 49 & 9.255 .680 & 1.715 \\
\hline $\begin{array}{l}\text { Metal, Eşya, } \\
\text { Makine Gereç }\end{array}$ & 0,0913 & 0,3821 & 65,55 & 0,68 & 0,1885 & 56 & 7.921 .153 & 8.872 \\
\hline Teknoloji & 0,0451 & 0,1001 & 153,93 & 0,56 & 0,5675 & 45 & 1.675 .242 & 3.637 \\
\hline $\begin{array}{l}\text { Ulaştırma\& } \\
\text { Haberleşme\& } \\
\text { Depolama }\end{array}$ & 0,0647 & 0,2910 & $-11,97$ & 0,60 & 0,0765 & 43 & 8.733 .401 & 19.702 \\
\hline $\begin{array}{l}\text { İnşaat } \\
\text { \&Bayındırlık }\end{array}$ & 0,0723 & 0,1301 & 32,38 & 0,30 & 0,2249 & 59 & 11.655 .925 & 27.510 \\
\hline Holdingler & 0,0416 & 0,1721 & 33,15 & 0,57 & 0,06554 & 40 & 17.508 .209 & 36.303 \\
\hline
\end{tabular}

\subsection{Bulgular}

Tablo 3'te değişkenlere ilişkin korelasyon katsayıları verilmiştir. Buna göre; araştırmada kullanılan bazı değişkenler arasında ilişki tespit edilirken, bazı değişkenler arasında korelasyona rastlanmamıştır. Buna bağlı olarak, şirketin aktif kârı ile şirketin yaşı arasında pozitif yönlü bir ilişki ( $\mathrm{p}=0,001<0,05 ; \mathrm{r}=0,834)$, şirketin likidite oranı ile nakit dönüş süresi arasında pozitif yönlü ilişki ( $p=0,001<0,05 ; r=0,852)$, şirketin faaliyet kârı ile finansal kaldıraç oranı arasında pozitif yönlü bir ilişki $(p=0,031<0,05 ; r=0,648)$, şirkette çalışan personel sayısı ile şirketin büyüklüğü arasında pozitif yönlü bir ilişki ( $p=0,001<0,05$ ; $r=0,861)$ söz konusudur. Ayrıca, şirketin aktif kârı ile nakit dönüş süresi ve şirket büyüklüğü arasında; likidite oranı ile şirket yaşı, finansal kaldıraç ve şirket büyüklüğü arasında, faaliyet kârı ile şirket yaşı, nakit dönüş süresi ve şirket büyüklüğü arasında; çalışan 
sayısı ile nakit dönüş süresi ve finansal kaldıraç oranı arasında anlamlı ilişki tespit edilememiştir.

Tablo 3. Korelasyon Tablosu

\begin{tabular}{|c|c|c|c|c|}
\hline Değişkenler & Şirket Yaşı & $\begin{array}{l}\text { Nakit Dönüs } \\
\text { Süresi }\end{array}$ & Finansal Kaldıraç & Şirket Büyüklüğü \\
\hline $\begin{array}{l}\text { Aktif Kârlılık } \\
\mathbf{r} \\
\mathbf{p}\end{array}$ & $\begin{array}{l}\mathbf{0 , 8 3 4} \\
\mathbf{0 , 0 0 1}\end{array}$ & $\begin{array}{l}0,095 \\
0,780\end{array}$ & $\begin{array}{l}-0,312 \\
0,351\end{array}$ & $\begin{array}{c}0,302 \\
0,367\end{array}$ \\
\hline $\begin{array}{l}\text { Likidite Oran1 } \\
\mathbf{r} \\
\mathbf{p}\end{array}$ & $\begin{array}{l}0,352 \\
0,288\end{array}$ & $\begin{array}{l}\mathbf{0 , 8 5 2} \\
\mathbf{0 , 0 0 1}\end{array}$ & $\begin{array}{l}-0,438 \\
0,178\end{array}$ & $\begin{array}{l}-0,530 \\
0,094\end{array}$ \\
\hline $\begin{array}{l}\text { Faaliyet Kârı } \\
\mathbf{r} \\
\mathbf{p}\end{array}$ & $\begin{array}{l}0,084 \\
0,806\end{array}$ & $\begin{array}{r}-0,556 \\
0,076\end{array}$ & $\begin{array}{l}0,648 \\
0,031\end{array}$ & $\begin{array}{l}0,358 \\
0,279\end{array}$ \\
\hline $\begin{array}{l}\text { Çalışan Sayısı } \\
\mathbf{r} \\
\mathbf{p}\end{array}$ & $\begin{array}{l}0,218 \\
0,520\end{array}$ & $\begin{array}{r}-0,472 \\
0,143\end{array}$ & $\begin{array}{l}-0,088 \\
0,797\end{array}$ & $\begin{array}{l}\mathbf{0 , 8 6 1} \\
\mathbf{0 , 0 0 1}\end{array}$ \\
\hline
\end{tabular}

\subsection{Hipotezlerin Test Edilmesi}

Kurulan birinci regresyon modelinde nakit dönüş süresi ile aktif kârlılık arasında ilişki incelenmiştir (Tablo 4). p değeri 0,780 > 0,05 olduğundan H1 hipotezi reddedilmiştir. Başka bir ifade örneklemimizin 2012-2016 yıllarına ilişkin veriler incelendiğinde, nakit dönüş süresinin aktif kârlılığı üzerinde etkisinin olmadığı görülmüştür.

Tablo 4. Nakit Dönüş Süresinin Aktif Kârlılığına Etkisi

\begin{tabular}{|l|l|l|l|}
\hline Model & Beta & $\mathbf{t}$ & $\mathbf{P}$ \\
\hline NDS & 0,095 & 0,288 & 0,780 \\
\hline
\end{tabular}

Kurulan ikinci regresyon modelinde nakit dönüş süresi ile faaliyet kârı arasında ilişki incelenmiştir ( Tablo 5). p değeri 0,076 > 0,05 olduğundan $\mathrm{H} 2$ hipotezi reddedilmiştir. Başka bir ifade ile örneklememizin 2012-2016 yıllarına ilişkin verileri incelendiğinde, nakit dönüş süresinin faaliyet kârı üzerinde etkisinin olmadığı görülmüştür.

Tablo 5. Nakit Dönüş Süresinin Faaliyet Kârlılığına Etkisi

\begin{tabular}{|l|l|l|l|}
\hline Model & Beta & T & P \\
\hline NDS & $-0,556$ & $-2,006$ & 0,076 \\
\hline
\end{tabular}

Kurulan üçüncü regresyon modelinde şirket büyüklüğü ile faaliyet kârı arasında ilişki incelenmiştir ( Tablo 6). p değeri 0,279> 0,05 olduğundan H3 hipotezi reddedilmiştir. Başka bir ifade ile örneklemimizin 2012-2016 yıllarına ilişkin verileri incelendiğinde, şirket büyüklüğünün faaliyet kârı üzerinde etkisinin olmadığı ortaya çıkmıştır. 
Tablo 6. Şirket Büyüklüğünün Faaliyet Kârına Etkisi

\begin{tabular}{|l|l|l|l|}
\hline Model & Beta & T & P \\
\hline Şirket Büyüklüğü & 0,358 & 1,151 & 0,279 \\
\hline
\end{tabular}

Kurulan dördüncü regresyon modelinde şirket büyüklüğü ile aktif kârı arasında ilişki incelenmiş̧tir (Tablo 7). p değeri 0,367> 0,05 olduğundan $\mathrm{H} 4$ hipotezi reddedilmiştir. Başka bir ifade ile örneklemimizin 2012-2016 yıllarına ilişkin verileri incelendiğinde, şirket büyüklüğünün aktif kârlılı̆̆ üzerinde etkisinin olmadığı ortaya çıkmıştır.

Tablo 7. Şirket Büyüklüğünün Aktif Kârına Etkisi

\begin{tabular}{|l|l|l|l|}
\hline Model & Beta & T & P \\
\hline Şirket Büyüklüğ̈̈ & 0,302 & 0,951 & 0,367 \\
\hline
\end{tabular}

Kurulan beşinci regresyon modelinde şirket yaşı ile aktif kârlılık arasında ilişki incelenmiş̧tir (Tablo 8). p değeri 0,001<0,05 olduğundan H5 hipotezi kabul edilmiştir. Beta 0,834 olduğundan şirket yaşı ile aktif kârlılık arasında yüksek düzeyde pozitif anlamlı etkisi tespit edilmiştir.

Tablo 8. Şirket Yaşının Aktif Kârına Etkisi

\begin{tabular}{|l|l|l|l|}
\hline Model & Beta & T & P \\
\hline Şirket Yaşı & 0,834 & 4,540 & 0,001 \\
\hline
\end{tabular}

Kurulan altınc1 regresyon modelinde şirket yaşı ile faaliyet kârlılı̆g 1 arasında ilişki incelenmiş̧tir (Tablo 9). p değeri 0,806 > 0,05 olduğundan H6 hipotezi reddedilmiştir. Başka bir ifade ile örneklemimizin 2012-2016 yıllarına ilişkin veriler incelendiğinde, şirket yaşının faaliyet kârı üzerinde etkisinin olmadığı görülmüştür.

Tablo 9. Şirket Yaşının Faaliyet Kârına Etkisi

\begin{tabular}{|l|l|l|l|}
\hline Model & Beta & T & P \\
\hline Şirket Yaşı & 0,084 & 0,253 & 0,806 \\
\hline
\end{tabular}

Kurulan yedinci regresyon modelinde çalışan sayısı ile aktif kârlılığı arasında ilişki incelenmiş̧tir ( Tablo 10). p değeri $0,565>0,05$ olduğundan $\mathrm{H} 7$ hipotezi reddedilmiştir.Başka bir ifade ileörneklemimizin 2012-2016 yıllarına ilişkin verileri incelendiğinde, çalışan sayısının aktif kârlılı̆̆ı üzerinde bir etkisinin olmadığı̆ görülmüştür.

Tablo 10. Çalışan Sayısının Aktif Kârlılığına Etkisi

\begin{tabular}{|l|l|l|l|}
\hline Model & Beta & T & P \\
\hline çalşan sayısı & 0,195 & 0,597 & 0,565 \\
\hline
\end{tabular}

Kurulan sekizinci regresyon modelinde çalışan sayısı ile faaliyet kârlılığ 1 arasında ilişki incelenmiştir (Tablo 11). p değeri 0,421 > 0,05 olduğundan H8 hipotezi reddedilmiştir. 
Başka bir ifade ile örneklemimizin 2012-2016 yıllarına ilişkin veriler incelendiğinde, çalışan sayısının faaliyet kârı üzerinde etkisinin olmadığ 1 görülmüştür.

Tablo 11. Çalışan Sayısının Faaliyet Kârlılı̆̆ına Etkisi

\begin{tabular}{|l|l|l|l|}
\hline Model & Beta & T & P \\
\hline çalışan sayısı & 0,271 & 0,843 & 0,421 \\
\hline
\end{tabular}

\section{SONUÇ}

$\mathrm{Bu}$ çalışma, finansal oranlar aracılığıyla çalışma sermayesi ile şirketin performansı arasındaki ilişkiyi incelemeyi amaçlamaktadır. Bu kapsamda BİST 50'de işlem gören 33 mali kuruluş olmayan şirkete ait 2012-2016 yıllarında elde edilen veriler sektörel bazda ortalamalar alınarak analiz edilmiştir. Çalışmaların sonuçları aşağıda açıklanmıştır:

Araştırmada çalışma sermayesinin başarısını ölçmede kullanılan gösterge nakit dönüş süresidir. Nakit dönüş süresinin hem aktif kârlılığı hem de faaliyet kârı ile arasında anlamlı ilişki belirlenememiştir.

BİST 50'de işlem gören mali kuruluş olmayan 33 şirketin örnekleme dahil edilmesi ve 2012-2016 yıllarında yer alan yıllık verilerden yararlanılması çalışmanın önemli bir kısıtı olarak değerlendirilmelidir.

Şirketlerin aktif kârları ile yaşları arasında pozitif yönlü ilişki tespit edilmiştir. Bu şirketin yaşam ömrünün kâr yaratmadaki etkisini göstermektedir. Şirketin likidite oranı ile nakit dönüş süresi arasında pozitif ilişki tespit edilmiştir. Likidite oranı, işletmelerin stokları nakde dönüştürememe durumunda bile likit varlıkları ile kısa vadeli borçlarını ödeyebilme gücünü gösteren orandır. Şirketin likiditesi nakit dönüş süresinden etkilendiği için likidite oran ile nakit dönüş süresi arasında pozitif ilişki olması beklenen bir durumdur. Şirketin faaliyet kârı ile finansal kaldıraç arasında pozitif yönlü ilişki tespit edilmiştir. Finansal kaldıraç oranı, varlıkların ne kadarlık kısmının borçla finanse edildiğini göstermektedir. Finansal kaldıraç oranının şirketin faaliyet kârı üzerinde olumlu etkisi olduğu belirlenmiştir. Başka bir ifade ile finansal kaldıraç oranının artması şirketin faaliyet kârını arttırmaktadır. Şirketin çalışan sayısı ile şirket büyüklüğü arasında pozitif ilişki vardır. $\mathrm{Bu}$, tahmin edilebilecek bir durumdur ve şirkette çalışan personel sayısı arttıkça varlık büyüklüğünün artma eğiliminde olduğu görülmektedir.

\section{KAYNAKLAR}

Aregbeyen, Omo(2013), “The Effects of Working Capital Management on The Profitability of Nigerian Manufacturing Firms", Journal of Business Economics and Management, 14(3), pp. 520-534.

Baños-Caballero, Sonia - García-Teruel, Pedro - Martínez-Solano, Pedro (2014), "Working Capital Management, Corporate Performanceand Financial Constraints", Journal of Business Research, 67(3),pp. 332-338.

Coşkun, Ender-Kök, Dündar(2011), “Çalışma Sermayesi Politikalarının Kârlılık Üzerine Etkisi: Dinamik Panel Uygulaması”, Ege Akademik Bakış Dergisi, 11(5),ss.77. 
Deloof, Marg (2003),“Does Working Capital Management Affect Profitability of Belgian Firms?", Journal of Business Finance \& Accounting, Vol. 30(3-4), pp.573-588.

Dinçergök, Burcu (2019), “İşletme Sermayesi Yönetimi ve Kârlllık İlişkisi: Doğrusal Olmayan İlişkinin BIST Kimya, Petrol, Kauçuk ve Plastik Ürünler Sektöründe Sinanması" , Muhasebe ve Finansman Dergisi, 82, Ekim, ss.162-176.

Ebben, Jay - Johnson, Alex (2011), "Cash Conversion Cycle Management in Small Firms Relationships with Liquidity, Invested Capital, and Firm Performance", Journal of Small Business \& Entrepreneurship, 24 (3), pp.381-396.

Ege,İlhan - Topaloğlu, Emre- Karakozak,Özlem(2016), "Nakit Dönüşüm Süresi Analizi: BIST-50 Endeksinde Yer Alan Şirketler Üzerine Ampirik Bir Uygulama”, Niğde Üniversitesi İ̈BF Dergisi, 9 (1), ss.181.

Gill, Amarjit- Biger, Nahum-Mathur, Neil (2010),“The Relationship Between Working Capital Management and Profitability: Evidence From The United States", Business and Economics Journal, 10(1), pp.1-9.

İşeri, Müge - Chambers, Nurgül (2003),"Üretim ve Perakende Ticaret Sektörlerinin Nakit Dönüşüm Süreçlerinin İrdelenmesi”, Mali Çözüm Dergisi, 62,ss.1-6.

Karadeniz, Erdinç (2012),“Turizm Sektörünün Nakit Dönüşüm Süresinin Analizi: İMKB Turizm Şirketleri ve TCMB Sektör Bilançoları Üzerinde Bir Araştırma", Cag University Journal of Social Sciences, 9(1), ss.123-130.

Keskin, Rıdvan - Gökalp, Füsun (2016),“Çalışma Sermaye Yönetiminin Firma Kârlılı̆̆ Üzerine Etkisi: Panel Veri Analizi”,Doğuş Üniversitesi Dergisi, 17 (1),ss.16.

Konak, Fatih - Güner, Nur (2016), “The Impact of Working Capital Management on Firm Performance: An Empirical Evidence From The BIST SME Industrial Index", International Journal of Trade, Economics and Finance, 7(2),pp.38-43.

Konuk, Filiz - Zeren, Feyyaz (2014), "Is Cash Conversion Cycles Optimum in Turkish Listed Food-Beverage Firms?", Theoretical \& Applied Economics, 21(12), pp.159-161.

Manuel, Jose - Lancaster, Carol- Steves, Jerry (1996), "Corporate Returns and Cash Conversion Cycles", Journal of Economics and Finance, 20 (1), pp.33-46.

Mansoori, Ebrahim - Muhammad, Joriah (2012),"The Effect of Working Capital Management on Firm's Profitability: Evidence From Singapore", Interdisciplinary Journal of Contemporary Research in Business, 4(5), pp.475-479.

Murugesu, Tharshiga (2013),"Effect of Cash Conversion Cycle on Profitability: Listed Plantation Companies İn Sri Lanka.",Research Journal of Finance and Accounting, 4(18),pp.132-137.

Nobanee, Haitham - Abdullatif, Modar - Alhajjar, Maryam ( 2011), "Cash Conversion Cycle and Firm's Performance of Japanese Firms",Asian Review of Accounting, 19, (2), pp.153- 156.

Padachi, Kesseven (2006), “Trends in Working Capital Management and Its İmpact on Firms' Performance: an Analysis of Mauritian Small Manufacturing Firms", International Review of Business Research Papers, 2(2), pp.45-58.

Sagan, John (1955), “Toward a Theory Of Working Capital Management”, The Journal of Finance, 10(2),pp.121-129. 
Sharma, A. K. - Kumar, Satish (2011), "Effect of Working Capital Management on Firm Profitability: Empirical Evidence From India", Global Business Review, 12(1), pp.159- 173.

Shin, Hyun Han - Soenen, Luc (1998),"Efficiency of Working Capital Management and Corporate Profitability", Financial Practice and Education, Vol 8(2), pp.37-45.

Sakarya,Şakir (2008), "Nakit Yönetiminde Nakit Dönüş Süresi Analizinin Kullanılması: İMKB'deki KOBİ'ler Üzerine Ampirik Bir Çalışma",Süleyman Demirel Üniversitesi İ̈BF Dergisi,13 (2), ss.237-241.

Saldanlı, Arif (2012), "Likidite ve Kârlılık Arasındaki İlişki - İMKB100 İmalat Sektörü Üzerine Ampirik Bir Çalışma",Süleyman Demirel Üniversitesi Sosyal Bilimler Enstitüsü Dergisi, 16, ss.168.

Tran, Hien - Malcolm, Abbott - Yap, Chee Jin (2017), “ How Does Working Capital Management Affect the Profitability of Vietnamese Small- and Medium-Sized Enterprises?, Journal of Small Business and Enterprise Development, 24 (1), pp.2-11.

Topaloğlu, Emre - Nur, Tuğba (2016),"Nakit Dönüşüm Süresinin Finansal Performansa Etkisi: Kurumsal Yönetim Endeksinde Bir Uygulama”, Akademik Bakış Uluslararası Hakemli Sosyal Bilimler Dergisi, 53,Ocak-Şubat, ss.305.

Uyar, Ali (2009), "The Relationship of Cash Conversion Cycle with Firm Size and Profitability: An Empirical Investigation in Turkey", International Research Journal of Finance and Economics, 24(2), ss.186-193.

Yazdanfar, Darush - Öhmen, Peter (2014), “The Impact Of Cash Conversion Cycle On Firm Profitability: An Empirical Study Based On Swedish Data", International Journal of Managerial Finance, 10(4), pp.443-452.

Yücel, Tülay - Kurt, Gülüzar (2002), "Nakit Dönüş Süresi, Nakit Yönetimi Ve Kârlılık: İMKB Şirketleri Üzerinde Ampirik Bir Çalışma”, İMKB Dergisi, 6(22),ss.2.

Zeidan, Rodrigo - Shapir, Offer (2017), "Cash Conversion Cycle and Value- Enhancing Operations: Theory and Evidence for a Free Lunch", Journal of Corporate Finance, 45, April, pp.203-219. 
